\title{
Accruals quality and the cost of debt: The European evidence
}

\begin{abstract}
Purpose - This paper aims to investigate the empirical relationship between the cost of debt $(C o D)$ and accruals quality $(A Q)$ of European listed firms during the period of 2005 to 2014 . Also, it aims to test the impact of the interrelationship between the financial crisis (2008-2009) and $A Q$ on $C o D$. Finally, we decompose $A Q$ into two components; the innate (Innate $A Q$ ) and discretionary components (DiscAQ) and test their relationships with $C o D$.
\end{abstract}

Yasser Eliwa, Andros Gregoriou, Audrey Paterson

Design/methodology/approach - To empirically examine the relationship between $A Q$ and $C o D$, a sample including 15-member states of the EU is constructed. $A Q$ proxy is based on the McNichols (2002) modification of Dechow and Dichev (2002) model. A univariate analysis and a multivariate analysis are conducted to examine the relationship between $A Q$ and $C o D$ after controlling for firm characteristics and institutional variables.

Findings - We find a significant negative association between $A Q$ and $C o D$ in a vast proportion of the 15 countries under review. Also, the results indicate that during the crisis period, creditors pay relatively more attention to the quality of accounting information than during the pre-crisis period when they determine $C o D$ of firms. Moreover, we report a link between the magnitude of this relationship and national characteristics and provide evidence of the significant effects of national characteristics and market forces on the $C o D$. Finally, we find that the Innate $A Q$ drives the relationship with $C o D$.

Practical implications - This paper provides up-to-date evidence of the economic consequences of IFRS and $A Q$. The results should, therefore, be of interest to managers, creditors, regulators and standard-setters.

Originality/value - To the best of our knowledge, this is the first study to investigate the effects of $A Q$ on $C o D$ for European listed firms. Also, it is the first to examine the impact of financial crisis on the association between $A Q$ on $C o D$.

Keywords: earnings quality $(E Q)$; accruals quality $(A Q)$; the cost of debt $(C o D)$; Europe

\section{Article Type: Research paper}




\section{INTRODUCTION}

The main objective of a financial accounting system is to help users to make valuable decisions. Consequently, it is expected in the capital market that high-quality accounting information supports investors and creditors to make better judgments and decisions (Ewert and Wagenhofer, 2012). This implies that accounting information plays a fundamental role in the capital market (Lim et al., 2015; Nahar et al., 2016). Accordingly, previous studies tried to find out how the accounting information in the capital market affects external suppliers of capital by examining accounting information quality influences on the cost of debt $(C o D)$ (Francis et al., 2006). This paper attempts to provide an answer to this question by empirically investigating the relationship between accruals quality $(A Q)$ as a measure of accounting quality and $C o D$ in 15 European countries.

Further, we decompose $A Q$ into two components, the innate component (Innate $A Q$ ), which reflects the economic fundamentals and business environment, and the discretionary component (DiscAQ), which reflects the management reporting choices, and test whether each component has the same effect on creditors' decisions in the EU market after the adoption of IFRS in 2005. Previous studies argue that both components are priced in the US market (Francis et al., 2005; Core et al., 2008).

In addition, all global capital markets have suffered from the financial crisis described in the media as the 'credit crunch' after the collapse of the US mortgage market in 2008. Of particular note is the effect the credit crunch had on the economic environment of European firms, which is characterised by a lack of liquidity (Duff and Einig, 2009; Iatridis and Dimitras, 2013; Bowen and Khan, 2014; Trombetta and Imperatore, 2014). In this context, we investigate the impact of macroeconomic factors - the 2008 financial crisis - on the relationship between $A Q$ and CoD.

Therefore, this study contributes to the growing area of accounting quality research in a number of ways. Firstly, this study has been one of the first attempts to thoroughly examine the effects of $A Q$ on $C o D$ for European listed firms. Further, using a sample from the European market has two advantages: (1) to test the influence of $A Q$ on $C o D$, it is essential to keep other elements constant. Accordingly, using the European setting is an appropriate choice as since 2005, European-listed firms have adopted the International Financial Reporting Standards (IFRS). 
Regardless of their nationality, all firms in the sample have, mandatorily, adopted the IFRS. Consequently, any differences among European countries regarding the strength of the relationship between $A Q$ and $C o D$ in the financial crisis cannot be linked to the differences of using local accounting standards. (2) Previous literature has used single-country samples, which leads to an uncertainty of external validity of the findings. Using a sample of European countries with a larger geographical area counterbalances country-specific factors and, therefore, provides solid evidence. Also, adding regulatory and institutional factors to the main model will make it possible to investigate the impact of those factors on the association between $A Q$ and $C o D$ (Filip and Raffournier, 2014).

Second, this study examines the impact of the financial crisis on the association between $A Q$ on $C o D$ for European listed firms. The financial crisis, the effects of which have been omitted by prior studies that examine the relationship between $A Q$ and $C o D$, has a significant effect on the firms' performance, which might motivate managers to manipulate earnings. In this regard, Filip and Raffournier (2014) assert that the consequences of the financial crisis on accounting quality are still not entirely explored and needs additional investigations.

Thirdly, this study investigates the separate impact of InnateAQ and DiscAQ on CoD in the EU. Most of the previous studies that discussed this relationship focused on the US and found that creditors price both Innate $A Q$ and Disc AQ in the capital market (Francis et al., 2005; Core et al., 2008). In the same vein, IFRS, the principles-based standards that have been applied in Europe since 2005, could offer management the opportunity to manipulate accounting information. However, it could help management to reflect the economic positions of firms correctly and report high-quality accounting information (Segovia et al., 2009; Jamal and Tan, 2010; Agoglia et al., 2011; Cohen et al., 2013).

We report evidence of a significant negative association between $A Q$ and $C o D$. This indicates that, in the European market, $A Q$ is a substantial determinant of $C o D$. Also, the results show that during the financial crisis, the association between $A Q$ and $C o D$ is stronger than during the pre-crisis period. This finding demonstrates the vital role of macroeconomic factors in the association between $A Q$ and $C o D$. In addition, it supports the notion that high $A Q$ is more likely during the crisis period than during the growth period. Finally, we divide $A Q$ into two components. (1) Innate $A Q$, motivated by economic fundamentals and the business environment, and (2) DiscAQ, motivated by the quality of accounting standards and managerial 
choices. We then test whether these components have significant effects on $C o D$. It shows that Innate $A Q$, in the pre-crisis period, has a stronger impact on $C o D$ than Disc $A Q$. During the crisis period, the results suggest that $C O D$ is significantly affected only by Innate $A Q$; however, DiscAQ has inverse effects on $C o D$. This is consistent with the opinion that IFRS decrease the information risk of DiscAQ in the EU market, and accordingly, leads to either positive or no relationship with $C o D$. We attribute this finding to IFRS, which have been adopted in the EU since 2005 .

The rest of this paper is designed as follows: Section (2) critically discusses the literature review, and hypotheses development; (3) outlines the sample and how to measure variables; (4) reports the empirical findings; and, finally, section (5) concludes.

\section{LITERATURE REVIEW}

A number of empirical accounting studies examine the relationship between earnings quality (EQ) and $C o D$ (e.g., Ahmed et al., 2002; Francis et al., 2005; Ashbaugh-Skaife et al., 2006; Bharath et al., 2008; Zhang, 2008; Gray et al., 2009). The primary question is that poor $E Q$ is linked with the high cost of capital (e.g., Mouselli et al., 2012; Artikis and Papanastasopoulos, 2016; Eliwa et al., 2016). This question is extracted from the theoretical studies and theories that support the view that high-quality accounting information is expected to reduce the cost of equity and debt capital, through decreasing information asymmetry and information risk (Easley and O'hara, 2004; Lambert et al., 2012).

Empirically, Ahmed et al. (2002) examine the association between earnings conservatism as a measure of $E Q$ and credit rating as a measure of $C o D$. They find that there is a significant positive association between earnings conservatism and credit ratings. Ashbaugh-Skaife et al. (2006) add to this research topic and examine the relationship between $E Q$ pre-issuing bonds and the credit rating at the issued time and find positive results. Also, Zhang (2008) tests the association between conservatism as a measure of $E Q$ and interest rate as a measure of $C o D$ and finds similar results.

Moving to $A Q$ as a unique measure of $E Q$, Francis et al. (2005) and Bharath et al. (2008) examine the impact of $A Q$ on $C o D$, and find a negative association between $A Q$ and $C o D$ in the US market. Nevertheless, as pointed out by Armstrong et al. (2010, p.218), a limitation of this research is that "absent performance pricing or renegotiation, interest rates are determined 
at the time the contract is initiated. Correlating current accounting quality and interest rates at the time the contract is initiated assumes that either accounting quality or credit quality, or both, are relatively persistent."

Using the Australian market, Gray et al. (2009) re-investigate the same association as Francis et al. (2005) and Bharath et al. (2008). They find a negative association between $A Q$ and $C o D$. Using the Belgian market, Vander Bauwhede et al. (2015) investigate the association between $A Q$ and $C o D$ of SMEs and find the same results. Moving to emerging markets, Song (2016) investigates the association between $A Q$ and bank loan syndicate structure in 11 emerging countries. Song also tests the interaction effects between governance standards and accounting quality on bank loan syndicates. He finds that firms with poor $A Q$ are expected to have a more concentrated loan syndicate. Furthermore, the results suggest that this relationship is more prominent for firms with superior governance.

Overall, these studies provide converging evidence of the association between $A Q$ and $C o D$. However, none of these studies have taken into consideration the impact of institutional factors on the association between $A Q$ and $C o D$. Therefore, we investigate whether there is a negative relationship between $E Q$ and $C o D$ of European listed firms after the adoption of IFRS. In particularly, the following hypothesis is tested:

\section{$H_{1}$ : The cost of debt is lower for firms with higher $A Q$ than firms with poorer $A Q$.}

Most prior studies examine solely the impact of the financial crisis on $E Q$ proxies, however, none of these studies examine the effects of the interrelationship between the financial crisis and $E Q$ proxies on $C o D$. For example, using a sample of nine Asian countries, Choi et al. (2011) find a significant impact of the crisis on the value relevance of the discretionary component of $E Q$. Conversely, they find no significant effect of the crisis on the relationship between the innate component of $E Q$ and value relevance.

Using a sample of five European countries, Iatridis and Dimitras (2013) investigate the association between $E Q$ and the financial crisis in 2008-2009. They find that three of these countries - Greece, Italy and Portugal - have a significant increase in earnings management during the crisis period compared to the pre-crisis period. Conversely, Kousenidis et al. (2013) 
examine the impact of financial crisis on seven $E Q$ proxies by sampling the same five countries. They find, during the crisis, most of $E Q$ proxies improved. Using a sample of European countries, both Filip and Raffournier (2014) and Arthur et al. (2015) find a significant increase in $E Q$ during the crisis period compared to the pre-crisis period.

In conclusion, these studies provide mixed evidence of the impact the financial crisis on $E Q$ proxies. Also, it is clear that none of these studies test the interrelations effects of the financial crisis and $A Q$ on $C o D$. Therefore, we are motivated by a question of whether the financial crisis has a significant impact on the relationship between $A Q$ and $C o D$. As such the following hypothesis is examined:

$\mathrm{H}_{2}$ : There is a significant positive impact of the financial crisis on the relationship between $A Q$ and $C o D$.

$A Q$ is affected by two primary factors; Innate $A Q$ and $\operatorname{Disc} A Q$. Innate $A Q$ reflects the operating environment and the business model of firms, while $\operatorname{Disc} A Q$, reflects the quality of accounting information and managerial choices (Francis et al., 2006). Francis et al. (2005) investigate whether the two components of $A Q$ have significant effects on $C o D$ using a sample of US firms. They find that Innate $A Q$ has a larger influence on $C o D$ than Disc $A Q$. Using a sample of the Australian market, Gray et al. (2009) re-investigate the same association and find that the association between total $A Q$ and $C o D$ is driven by Innate $A Q$, with no apparent evidence that Disc $A Q$ affects $C o D$.

Since 2005, all listed EU firms were obliged to adopt IFRS. As such, they are required to follow IFRS in the preparation of their financial statements from 2005 onwards (Iatridis, 2008; Eliwa et al., 2016). The primary objectives of adopting IFRS are to improve the quality of reported accounting information and to accomplish better comparability and transparency of this information (Ball, 2006; Iatridis, 2010; Iatridis and Dimitras, 2013; Dayanandan et al., 2016). The proponents of IFRS contend that IFRS improves the quality of accounting information that is available to users, e.g., investors and creditors more than Domestic Accounting Standards (DAS). They argue that IFRS decrease earnings management in financial reporting and focus significantly on the capital market benefits such as improving liquidity and market efficiency 
along with lowering the cost of equity capital. Consequently, it is more relevant to users than most of DAS (Gassen and Sellhorn, 2006; Ding et al., 2007; Chen et al., 2010; Iatridis, 2010; Horton et al., 2013; Dayanandan et al., 2016). In relation to our sample, it is unclear whether the Innate $A Q$ and DiscAQ will influence $C o D$ equally as previous studies (e.g., Francis et al. 2005). This prompts our re-examination of the relationship between $C o D$ and both the Innate $A Q$ and DiscAQ. The significant influence of creditors on borrowing firms is expected to reduce the effect of information risk arising from Disc $A Q$. However, it is unclear how the adoption of IFRS will influence this relationship. Along the lines of previous research, our hypothesis tests the impact of Innate $A Q$ and DiscAQ on COD in Europe after the adoption of IFRS. Specifically, we test the following hypothesis:

H3: InnateAQ has a stronger negative effect on CoD compared to DiscAQ.

\section{METHODOLOGY AND SAMPLE SELECTION}

\section{i. Accruals quality (AQ)}

Our $A Q$ proxy is based on the McNichols (2002) modification of Dechow and Dichev (2002) model. Then, we rank $A Q$ proxy and form ten deciles. Firms in decile ten have the largest values of the proxy which represent poor $A Q$, while firms in decile one have the lowest values of the proxy and represent high $A Q$ (Francis et al., 2005).

\section{ii. $\quad$ The Cost of debt (CoD)}

$C o D$ is measured as the interest expense of a firm in year $t$, deflated by the average interestbearing debt outstanding during years $t$ and $t+1$ (Francis et al., 2005; Gray et al., 2009).

\section{iii. Control variables of the main model}

In this section, we discuss the variables regularly used in the prior studies and consistently found to have a strong relationship with $C o D$; these are firm size, leverage, ROA, interest coverage rate (IntCov) and earnings volatility $(\sigma N I B E)$. We measure firm size as a natural logarithm of total assets in year $t$. Leverage is the ratio of total debt to total assets in year $t$. IntCov is the total operating income divided by total interest expense in year $t$. Earnings 
volatility is the ten-year standard deviation (SD) of net income, divided by average assets (Francis et al., 2005; Gray et al., 2009; Lai et al., 2015).

We expect a negative relationship between $C o D$ and firm size. Larger firms have lower information asymmetry and more external financing resources than smaller firms. So, it is expected that large firms have a lower interest rate. Firms with lower leverage show better solvency than firms with higher leverage, so it is expected for those firms to borrow at lower costs. ROA is considered as an agreed measure of profitability. So, firms with higher ROA are in a better financial position and often acquire loans with lower borrowing costs. Interest coverage rate (IntCov) is a measure of firms' capabilities to pay its interest. So, it is likely that firms with a higher rate of interest coverage to have lower $C o D$. Finally, we expect a positive association between earnings variability and $C o D$. Firms with high level of earnings volatility are expected to borrow at higher costs.

\section{iv. Sample selection}

Our sample covers all non-financial firms in 15-member states of the EU. Due to the significant impact of IFRS on $E Q$, this study focuses on these "early adopters" EU members. Luxembourg is excluded due to inadequate observations. Although Norway is not a member of the EU, it has been added to the sample because it has forced all list companies to use IFRS since 2005 .

The data consist of up to ten years of annual financial reports of publicly traded companies in the EU. The sample is constrained by one condition: each firm needs as a minimum seven successive years of data to calculate $A Q$. In particular, the model of $A Q$ needs five consecutive annual residuals and both lag and lead CFO. In total, the final sample consists of 32,126 firmyear observations over the period of 2005 to 2014. We obtained the required data from the Thomson Reuters DataStream database. Panels A and B of table 1 report the number of firms per country and industry. To remove the effects of extreme values, we winsorised all variables to the 1st and 99th percentiles (Francis et al., 2005).

Panel $\mathrm{C}$ of table 1 provides descriptive statistics on $A Q, C o D$ and firm characteristics for the pooled sample. For example, the mean of $A Q$ is 0.11 and the median is 0.07 . The mean of $C o D$ is 0.09 and the median is 0.07 . The mean of leverage is 0.22 and the median is 0.18 . The mean of firm size is 5.04 and the median is 4.89 . The mean of interest coverage is 10.15 and the median is 4.49 . The mean of earnings volatility is 0.13 and the median is 0.06 . Moreover, Panel 
$\mathrm{C}$ reports information of other variables. For example, the average of total assets is 2,900 million dollars, and the median of total assets is 132 million dollars. The average of sales is 2,200 million dollars and the median of sales is 114.5 million dollars.

Panel D of table 1 reports the correlations between $C o D, A Q$ and control variables. It shows a significant positive correlation between $C o D$ and $A Q$, which indicates that firms with poor AQ (large values) have high $C o D$. Also, it shows significant negative correlations between $C o D$ and firm size, ROA and interest coverage. There is a significant positive correlation between $C o D$ and both leverage and $\sigma(N I B E)$. The correlation between $A Q$ and any control variable is less than 49\%; therefore, the multicollinearity problem is limited in the model.

\section{[Insert Table 1 here]}

\section{MAIN TESTS AND RESULTS}

Univariate analysis of $C o D$ is conducted across quintiles sorted on $A Q$ from the lowest to the highest. We rank $A Q$ proxy and create ten deciles. Based on the definition of $A Q$ measure, decile ten represents low $A Q$, and decile one represents high $A Q$. Table 2 represents information on the differences between the average of $C o D$ on both low (decile 10) and high (decile 1) $A Q$ quintiles through the period of 2005 to 2014. The results show that low $A Q$ quintile $(\mathrm{Q} 10)$ has a significantly larger average of $C o D$ than high $A Q$ quintile (Q1). Also, the table reports that Q10 has a considerably larger average of $C o D$ than $\mathrm{Q} 1$ in the crisis (20082009 ) and pre-crisis (2005-2007) periods. This table also reports that, in both periods, firms in Q10 have a significantly larger average of $C o D$ than firms in Q1. However, in the crisis period, there is a larger significant difference between Q1 and Q10 than the pre-crisis period. In the crisis period, the difference between the average of $C o D$ values of the two said quintiles (Q10 and Q1) is 0.039 with t-statistic 14.27. However, in the pre-crisis period, the difference is 0.024 with t-statistic 9.19. This finding can be interpreted as in the crisis period, creditors give more attention to the quality of accounting information than a pre-crisis period. To sum up, these results provide initial evidence that $A Q$ is negatively associated with $C o D$ in the European market. 


\section{[Insert Table 2 here]}

\section{i. $\quad$ The relationship between $A Q$ and $C o D$ for $E U$ listed firms}

In this section, the results of the primary model are reported. In particular, we examine the relationship between $C o D$ and $A Q$ in addition to control variables and country differences.

$$
\begin{aligned}
\text { CoD }=\alpha+ & \beta_{1} \text { Leverage }+\beta_{2} \text { Size }+\beta_{3} R O A+\beta_{4} \text { IntCov } \\
& +\beta_{5} \sigma(N I B E)+\beta_{6} A Q+\beta_{7} \text { Crisis }+\beta_{8} \text { Crisis } * A Q \\
& +\beta_{9} \text { ShareProt }+\beta_{10} \text { LawEnforc } \\
& +\beta_{11} \text { LegalTradition }+\beta_{12} \text { LegalOrigin } \\
& +\beta_{13} \text { ImpoEquity }+v
\end{aligned}
$$

Where:

CoD is the cost of debt;

Size is a natural logarithm of total assets;

Leverage is total debt of a firm deflated by total assets;

$R O A$ is net income before extraordinary items deflated by total assets;

IntCov is total operating income deflated by total interest expense;

$\sigma$ is the standard deviation calculated using the previous ten years of data;

$N I B E$ is the net income before extraordinary items (NIBE) divided by average assets;

$A Q$ is accruals quality proxy.

Crisis is a categorical variable equal to zero for years 2005, 2006 and 2007 (the pre-crisis period), one for the years 2008 and 2009 (the crisis period), and two for the years after 2009 (the post-crisis);

ShareProt is the Strength of Investor Protection index;

LawEnforc is the Rule of Law index;

LegalTradition: is a categorical variable equal to zero for code-law countries (CD), and one for common-law countries $(\mathrm{CM})$;

LegalOrigin: is a categorical variable equal to zero for German origin, one for French origin, two for Scandinavian origin and three for English origin.

ImpoEquity is the Importance of Equity Market index, which is measured based on the model of La Porta et al. (1997).

\section{a. The effect of financial crisis on the relationship between $A Q$ and $C o D$ for $E U$ listed firms}

We divide the sample period (2005-2014) into three periods: 'the pre-crisis' for years 2005, 2006 and 2007, 'the crisis period' for years 2008 and 2009, and 'the post-crisis period' for years after 2009. We test the interaction effects between financial crisis and $A Q$ on $C o D$ by adding the interaction variable. 


\section{b. The impact of country differences on the association between $A Q$ and $C o D$}

Prior studies suggest that country characteristics have a significant impact on $E Q$ (e.g., Ball et al., 2003; Leuz et al., 2003; Li Eng and Lin, 2013; Filip and Raffournier, 2014; Song, 2015). Therefore, we examine the impact of these characteristics on the relationship between $A Q$ and CoD. These characteristics are the legal environment and market forces.

\section{The impact of the legal environment}

A common argument in prior studies is that there is a significant positive relationship between $E Q$ and the level of protection of investors in each country. It is based on the notion that high level of protection available in a country can limit the profit of insider trading, thus it decreases their incentive to engage in earnings management activities in this country (Kinnunen and Koskela, 2003; Leuz et al., 2003; Haw et al., 2004; Burgstahler et al., 2006; Filip and Raffournier, 2014). Based on prior literature, we add investor protection variable to Equation (1). This variable is measured using an index provided by the World Bank named the Strength of Investor Protection Index (ShareProt). This measure is based on the average of three indices measuring the extent of director liability, the scope of disclosure, and the ease of shareholder suits in each country (Filip and Raffournier, 2014).

Also, strong legal rules are essential to assure the protection of investors' rights (Daske et al., 2008; DeFond et al., 2007; Burgstahler et al., 2006). Therefore, our study adds the legal rules as a control variable, which is measured using the index provided by the World Bank named the Rule of Law Index (LawEnforc). It shows the level of confidence that citizens have in the legal rules of their country. In particular, this measure covers four issues: the court system, the police, the contract enforcement quality, and property rights (Filip and Raffournier, 2014). A negative relationship between $C o D$ and law enforcement is expected.

Based on La Porta et al. (1998), we add two other proxies: the Legal Origin, and the Legal Tradition. The former is classified into four main types: French, Scandinavian, English, and German origins. The latter is classified into code-law and common-law countries.

\section{The influence of market forces}

There are two types of financial systems: market and bank-oriented. The two systems determine how companies raise funds. In the bank-oriented system, the bank is the main source of funds for companies, and in the market-oriented system, the stock market is the main source 
of funds. Prior studies argue that in the market-oriented system there is a higher demand for quality of earnings by shareholders than in the bank-oriented system, possibly because in the latter, information asymmetry is resolved through insider communications with management (Ball et al., 2000; Ball et al., 2003; Burgstahler et al., 2006).

Following La Porta et al. (1997) and Leuz et al. (2003), we measure the importance of the stock market in an economy (ImpoEquity) using the average rank of three measures: (1) the total market capitalisation held by minorities divided by gross national product (GNP); (2) the number of listed domestic firms compared with population; (3) and number of IPOs compared with population. A high value on this measure shows that the financial system in the country depends more on market-based financing than on bank-based financing.

Newey and West (1987) standard errors pooled regression is used to test Equation (1). This regression type mitigates the problems of autocorrelation and heteroscedasticity effects. The results are reported in table 3 . The results show a significantly negative association between $A Q$ and $C o D$. We interpret these results as a sign that as firms' earnings quality decreases, the amount of interest that creditors are willing to receive for a dollar of debt increases for such firms. In addition, $A Q$ is a major determinant for creditors decision models, which is consistent with previous studies and thus supports the hypothesis of $\left(\mathrm{H}_{1}\right)$.

Also, table 3 shows a significant effect of the financial crisis on the relationship between $A Q$ and $C o D$. This result could be interpreted as creditors showing more interest in $A Q$ during the crisis period compared to the pre-crisis period. In particular, the slope coefficient of $A Q$ in the pre-crisis period is 0.0014 . While, in the crisis period, there was an increase in the slope coefficient to $0.0029(0.0014+0.0015)$. This indicates that the sensitivity of $C o D$ to $A Q$ was considerably higher (0.0029) during the crisis period than in the pre-crisis period. Thus, we accept the hypothesis of $\left(\mathrm{H}_{2}\right)$.

Moreover, table 3 shows a significant negative association between $C o D$ and both shareholder protection and law enforcement. This indicates a higher $C o D$ with lower shareholder protection, which is consistent with prior studies. The results also show a significant positive association between $C o D$ and legal tradition, which indicates that $C O D$ is lower in the codelaw system than the common-law system. The results also show a significant negative association between $C o D$ and both legal origin and the importance of the stock market. This 
result indicates that countries with financial systems that rely more on market-oriented financing have higher $C o D$ than those countries that rely on bank-based financing.

Moving to control variables, table 3 reports significant negative associations between $C o D$ and Size, leverage and $R O A$, which is consistent with previous studies (e.g., Francis et al., 2005; Grey et al., 2008). Firms with high $R O A$ have lower $C o D$ and large firms have relatively lower $C o D$ compared to small firms. Also, firms with high leverage have higher $C o D$. Lastly, the table reports a positive association between $C o D$ and both IntCov, and earnings variability $(\sigma(N I B E))$, which is consistent with prior studies (e.g., Francis et al., 2005; Grey et al., 2008).

\section{[Insert Table 3 here]}

\section{ii. The effects of $A Q$ components on CoD}

Total $A Q$ can be divided into two components: Innate $A Q$, which reflects the operating environment and business model, and DiscAQ, which reflects the discretion in financial reporting (Francis et al., 2005; Charitou et al., 2007; Gray et al., 2009). Using the model of Francis et al. (2005), we divided total $A Q$ into these two components.

Table 4 reports the results of regressing the $C o D$ on both $A Q$ components. It shows that the Innate $A Q$ has a larger coefficient than the Disc $A Q$ coefficient by a factor of six, and it shows stronger significance than the DiscAQ coefficient. Economically, the largest influence of Innate $A Q$ increases $C o D$ by 414 (46*9) basis points between low and high Innate $A Q$ firms, whereas the influence of DiscAQ is $72(8 * 9)$ basis points. This finding suggests that creditors allocate higher $C o D$ to firms with poor $A Q$ related to Innate $A Q$, compared to poor $A Q$ related to $\operatorname{DiscAQ}$. However, in the crisis period, the results show that the discretionary component has a positive impact on $C o D$, which indicates that creditors punish firms with high Disc $A Q$ during the crisis period by increasing $C o D$. Finally, the results show that all country characteristics have significant associations with $C o D$.

\section{[Insert Table 4 here]}

\section{iii. Robustness tests}

In this section, we report the sensitivity tests that have been performed on our results. First, we use the raw values of $A Q$ instead of decile ranks of $A Q$ and run the test. We find a significant 
negative association between $A Q$ and $C o D$, which is consistent with the findings of the main test. Results are reported in table 5. Second, we use panel regressions with fixed and random effects for $C o D$. Based on Hausman test, it is found that fixed-effects model is relatively proper than the random-effects model. Based on the fixed-effects model, there is a significant negative association between $A Q$ and $C o D$, which is consistent with the findings of the main test. The results are reported in table 6.

\section{[Insert Table 5 here] \\ [Insert Table 6 here]}

\section{CONCLUSIONS}

This study extends the analysis of prior studies and investigates the impact of quality of earnings on $C o D$ for a sample of European listed firms through the period 2005-2014. We use $A Q$ as a proxy of $E Q$. We calibrate this proxy against $C o D$, a summary indicator of creditors' decisions, to study whether $A Q$ is viewed by creditors as conferring the maximum capital market advantage. We generally find a statistically significant negative relationship between $C o D$ and $A Q$. We interpret these results as a sign that, as earnings quality of a firm decreases, the amount of interest that creditors are willing to receive for a dollar of debt increases for such firms.

We also examine the impact of macroeconomic conditions - the financial crisis - on the association between $A Q$ and $C o D$ of European listed firms. The results suggest that, during the crisis period, the creditors' allocation decisions were strongly affected by the level of $E Q$ than the pre-crisis period. This finding demonstrates the influence of macroeconomic factors on the strength of the association between accounting information and capital market participants.

Although the European countries are comparatively homogeneous in economic and political factors, the magnitude of the relationship between $A Q$ and $C o D$ varies from one country to another. We indicate that the national features have a significant impact on the relationship between $A Q$ and $C o D$.

We also examine the separate effects of Innate $A Q$ and Disc $A Q$ on $C o D$. The result suggests that the Innate $A Q$ has a larger effect on the $C o D$ than DiscAQ. This result is consistent with the view that information uncertainty related to Innate $A Q$ is relatively fundamental, compared 
to the information uncertainty related to $\operatorname{Disc} A Q$, which can easily transfer from one period to another. This finding suggests that creditors reward Innate $A Q$ by reducing $C o D$.

To conclude, the results demonstrate the usefulness of accounting information to creditors, who reward high $A Q$ by determining a lower interest rate $(C o D)$. These results are relevant to managers, regulators and standard setting bodies. For managers, it is expected to work towards increasing the quality of earnings to reduce $C o D$. For regulators and standard setting bodies, the results show that the accounting information has a significant impact on market participants under IFRS in both code-law and common-law countries. This is important for them, mainly, when they prepare to change or review the accounting standards and regulations.

Based on prior studies, there is no consensus among researchers for a precise measure of $E Q$ (Dechow et al., 2010; Walker, 2013). Thus, it is interesting if future research employs different measures of $E Q$ such as earnings persistence and earnings predictability, and compares their effects on $C o D$. 


\section{REFERENCES}

Agoglia, C. P., Doupnik, T. S. \& Tsakumis, G. T. (2011) Principles-based versus rules-based accounting standards: The influence of standard precision and audit committee strength on financial reporting decisions. The Accounting Review, 86(3), 747-767.

Ahmed, A. S., Billings, B. K., Morton, R. M. \& Stanford-Harris, M. (2002) The role of accounting conservatism in mitigating bondholder-shareholder conflicts over dividend policy and in reducing debt costs. The Accounting Review, 77(4), 867-890.

Armstrong, C. S., Guay, W. R. \& Weber, J. P. (2010) The role of information and financial reporting in corporate governance and debt contracting. Journal of Accounting and Economics, 50(2), 179-234.

Arthur, N., Tang, Q. \& Lin, Z. S. (2015) Corporate accruals quality during the 2008-2010 Global Financial Crisis. Journal of International Accounting, Auditing and Taxation, $25,1-15$.

Artikis, P. G. \& Papanastasopoulos, G. A. (2016) Implications of the cash component of earnings for earnings persistence and stock returns. The British Accounting Review, 48(2), 117-133.

Ashbaugh-Skaife, H., Collins, D. W. \& LaFond, R. (2006) The effects of corporate governance on firms' credit ratings. Journal of Accounting and Economics, 42(1), 203243.

Ball, R. (2006) International Financial Reporting Standards (IFRS): Pros and cons for investors. Accounting and Business Research, 36(supplement), 5-27.

Ball, R., Kothari, S. \& Robin, A. (2000) The effect of international institutional factors on properties of accounting earnings. Journal of Accounting and Economics, 29(1), 1-51.

Ball, R., Robin, A. \& Wu, J. S. (2003) Incentives versus standards: Properties of accounting income in four East Asian countries. Journal of Accounting and Economics, 36(1), 235270.

Bharath, S. T., Sunder, J. \& Sunder, S. V. (2008) Accounting quality and debt contracting. The Accounting Review, 83(1), 1-28.

Bowen, R. M. \& Khan, U. (2014) Market reactions to policy deliberations on fair value accounting and impairment rules during the financial crisis of 2008-2009. Journal of Accounting and Public Policy, 33(3), 233-259.

Burgstahler, D. C., Hail, L. \& Leuz, C. (2006) The importance of reporting incentives: earnings management in European private and public firms. The Accounting Review, 81(5), 983-1016.

Charitou, A., Lambertides, N. \& Trigeorgis, L. (2007) Managerial discretion in distressed firms. The British Accounting Review, 39(4), 323-346.

Chen, H., Tang, Q., Jiang, Y. \& Lin, Z. (2010) The role of international financial reporting standards in accounting quality: Evidence from the European Union. Journal of International Financial Management \& Accounting, 21(3), 220-278.

Choi, J.-H., Kim, J.-B. \& Lee, J. J. (2011) Value relevance of discretionary accruals in the Asian financial crisis of 1997-1998. Journal of Accounting and Public Policy, 30(2), 166-187.

Cohen, J. R., Krishnamoorthy, G., Peytcheva, M. \& Wright, A. M. (2013) How does the strength of the financial regulatory regime influence auditors' judgments to constrain aggressive reporting in a principles-based versus rules-based accounting environment? Accounting Horizons, 27(3), 579-601. 
Core, J. E., Guay, W. R. \& Verdi, R. (2008) Is accruals quality a priced risk factor? Journal of Accounting and Economics, 46(1), 2-22.

Daske, H., Hail, L., Leuz, C. \& Verdi, R. (2008) Mandatory IFRS reporting around the world: Early evidence on the economic consequences. Journal of Accounting Research, 46(5), 1085-1142.

Dayanandan, A., Donker, H., Ivanof, M. \& Karahan, G. (2016) IFRS and accounting quality: legal origin, regional, and disclosure impacts. International Journal of Accounting \& Information Management, 24(3), 296-316.

Dechow, P., Ge, W. \& Schrand, C. (2010) Understanding earnings quality: A review of the proxies, their determinants and their consequences. Journal of Accounting and Economics, 50(2), 344-401.

Dechow, P. M. \& Dichev, I. D. (2002) The quality of accruals and earnings: The role of accrual estimation errors. The Accounting Review, 77(s-1), 35-59.

DeFond, M., Hung, M. \& Trezevant, R. (2007) Investor protection and the information content of annual earnings announcements: International evidence. Journal of Accounting and Economics, 43(1), 37-67.

Ding, Y., Hope, O.-K., Jeanjean, T. \& Stolowy, H. (2007) Differences between domestic accounting standards and IAS: Measurement, determinants and implications. Journal of Accounting and Public Policy, 26(1), 1-38.

Duff, A. \& Einig, S. (2009) Understanding credit ratings quality: Evidence from UK debt market participants. The British Accounting Review, 41(2), 107-119.

Easley, D. \& O'hara, M. (2004) Information and the cost of capital. The Journal of Finance, 59(4), 1553-1583.

Eliwa, Y., Haslam, J. \& Abraham, S. (2016) The association between earnings quality and the cost of equity capital: Evidence from the UK. International Review of Financial Analysis, 48, 125-139.

Ewert, R. \& Wagenhofer, A. (2012) Earnings management, conservatism, and earnings quality. Foundations and Trends ( $R$ ) in Accounting, 6(2), 65-186.

Filip, A. \& Raffournier, B. (2014) Financial crisis And earnings management: The European evidence. The International Journal of Accounting, 49(4), 455-478.

Francis, J., LaFond, R., Olsson, P. \& Schipper, K. (2005) The market pricing of accruals quality. Journal of Accounting and Economics, 39(2), 295-327.

Francis, J., Olsson, P. \& Schipper, K. (2006) Earnings quality. Foundations and Trends ${ }^{\circledR}$ in Accounting, 1(4), 259-340.

Gassen, J. \& Sellhorn, T. (2006) Applying IFRS in Germany-determinants and consequences. Betriebswirtschaftliche Forschung und Praxis, 58(4), 365-386.

Gray, P., Koh, P. S. \& Tong, Y. H. (2009) Accruals quality, information risk and cost of capital: Evidence from Australia. Journal of Business Finance \& Accounting, 36(1-2), 51-72.

Haw, I. M., Hu, B., Hwang, L. S. \& Wu, W. (2004) Ultimate ownership, income management, and legal and extra-legal institutions. Journal of Accounting Research, 42(2), 423-462.

Horton, J., Serafeim, G. \& Serafeim, I. (2013) Does mandatory IFRS adoption improve the information environment? Contemporary Accounting Research, 30(1), 388-423.

Iatridis, G. (2008) Accounting disclosure and firms' financial attributes: Evidence from the UK stock market. International Review of Financial Analysis, 17(2), 219-241.

Iatridis, G. (2010) International Financial Reporting Standards and the quality of financial statement information. International Review of Financial Analysis, 19(3), 193-204. 
Iatridis, G. \& Dimitras, A. I. (2013) Financial crisis and accounting quality: Evidence from five European countries. Advances in Accounting, 29(1), 154-160.

Jamal, K. \& Tan, H.-T. (2010) Joint effects of principles-based versus rules-based standards and auditor type in constraining financial managers' aggressive reporting. The Accounting Review, 85(4), 1325-1346.

Kinnunen, J. \& Koskela, M. (2003) Who is miss world in cosmetic earnings management? A cross-national comparison of small upward rounding of net income numbers among eighteen countries. Journal of International Accounting Research, 2(1), 39-68.

Kousenidis, D. V., Ladas, A. C. \& Negakis, C. I. (2013) The effects of the European debt crisis on earnings quality. International Review of Financial Analysis, 30, 351-362.

La Porta, R., Lopez-de-Silanes, F. \& Shleifer, A. (1998) Law and finance. Journal of Political Economy, 106, 1113-1155.

La Porta, R., Lopez-de-Silanes, F., Shleifer, A. \& Vishny, R. W. (1997) Legal determinants of external finance. The Journal of Finance, 1131-1150.

Lai, S.-C., Lin, Y.-S., Lin, Y.-H. \& Huang, H.-W. (2015) XBRL adoption and cost of debt. International Journal of Accounting \& Information Management, 23(2), 199-216.

Lambert, R. A., Leuz, C. \& Verrecchia, R. E. (2012) Information asymmetry, information precision, and the cost of capital. Review of Finance, 16(1), 1-29.

Leuz, C., Nanda, D. \& Wysocki, P. D. (2003) Earnings management and investor protection: an international comparison. Journal of Financial Economics, 69(3), 505-527.

Li Eng, L. \& Lin, J. (2013) Accounting quality of German and UK cross-listings. International Journal of Accounting \& Information Management, 21(3), 192-208.

Lim, J., Lee, J. \& Chang, J. (2015) Financial reporting quality of target companies and acquirer returns: evidence from Korea. International Journal of Accounting \& Information Management, 23(1), 16-41.

McNichols, M. F. (2002) Discussion of the quality of accruals and earnings: The role of accrual estimation errors. The Accounting Review, 77(Supplement), 61-69.

Mouselli, S., Jaafar, A. \& Hussainey, K. (2012) Accruals quality vis-à-vis disclosure quality: Substitutes or complements? The British Accounting Review, 44(1), 36-46.

Nahar, S., Azim, M. \& Anne Jubb, C. (2016) Risk disclosure, cost of capital and bank performance. International Journal of Accounting \& Information Management, 24(4), 476-494.

Newey, W. K. \& West, K. D. (1987) A simple, positive semi-definite, heteroskedasticity and autocorrelation consistent covariance matrix. Econometrica: Journal of the Econometric Society, 55(3), 703-708.

Segovia, J., Arnold, V. \& Sutton, S. G. (2009) Do principles-vs. rules-based standards have a differential impact on US auditors' decisions. Advances in Accounting Behavioral Research, 12, 61-84.

Song, L. (2015) Accounting disclosure, stock price synchronicity and stock crash risk: An emerging-market perspective. International Journal of Accounting \& Information Management, 23(4), 349-363.

Song, L. (2016) Accounting quality and financing arrangements in emerging economies. International Journal of Accounting and Information Management, 24(1), 2-19.

Trombetta, M. \& Imperatore, C. (2014) The dynamic of financial crises and its nonmonotonic effects on earnings quality. Journal of Accounting and Public Policy, 33(3), 205-232.

Vander Bauwhede, H., De Meyere, M. \& Van Cauwenberge, P. (2015) Financial reporting quality and the cost of debt of SMEs. Small Business Economics, 45(1), 149-164. 
Walker, M. (2013) How far can we trust earnings numbers? What research tells us about earnings management. Accounting and Business Research, 43(4), 445-481.

Zhang, J. (2008) The contracting benefits of accounting conservatism to lenders and borrowers. Journal of Accounting and Economics, 45(1), $27-54$. 
Table 1

Panel A: Total number of firms per country and year ${ }^{\text {a }}$

\begin{tabular}{|c|c|c|c|c|c|c|c|c|c|c|c|c|c|c|c|c|c|c|c|c|c|c|}
\hline \multirow{2}{*}{$\begin{array}{c}\text { Country } \\
\text { Austria }\end{array}$} & \multicolumn{2}{|c|}{2005} & \multicolumn{2}{|c|}{2006} & \multicolumn{2}{|c|}{2007} & \multicolumn{2}{|c|}{2008} & \multicolumn{2}{|c|}{2009} & \multicolumn{2}{|c|}{2010} & \multicolumn{2}{|c|}{2011} & \multicolumn{2}{|c|}{2012} & \multicolumn{2}{|c|}{2013} & \multicolumn{2}{|c|}{2014} & \multicolumn{2}{|c|}{ Total } \\
\hline & 38 & $1 \%$ & 38 & $1 \%$ & 44 & $1 \%$ & 46 & $1 \%$ & 50 & $1 \%$ & 48 & $1 \%$ & 47 & $1 \%$ & 48 & $1 \%$ & 46 & $1 \%$ & 44 & $1 \%$ & 449 & $1 \%$ \\
\hline Belgium & 55 & $2 \%$ & 55 & $2 \%$ & 67 & $2 \%$ & 76 & $2 \%$ & 81 & $2 \%$ & 82 & $2 \%$ & 82 & $2 \%$ & 78 & $2 \%$ & 75 & $2 \%$ & 75 & $2 \%$ & 726 & $2 \%$ \\
\hline Denmark & 111 & $4 \%$ & 110 & $4 \%$ & 106 & $3 \%$ & 116 & $3 \%$ & 119 & $3 \%$ & 120 & $3 \%$ & 121 & $4 \%$ & 122 & $4 \%$ & 122 & $4 \%$ & 117 & $4 \%$ & 1,164 & $4 \%$ \\
\hline Finland & 105 & $4 \%$ & 106 & $4 \%$ & 109 & $3 \%$ & 111 & $3 \%$ & 111 & $3 \%$ & 109 & $3 \%$ & 106 & $3 \%$ & 107 & $3 \%$ & 107 & $3 \%$ & 106 & $3 \%$ & 1,077 & $3 \%$ \\
\hline France & 464 & $16 \%$ & 472 & $16 \%$ & 480 & $15 \%$ & 489 & $15 \%$ & 503 & $14 \%$ & 489 & $14 \%$ & 472 & $14 \%$ & 462 & $14 \%$ & 457 & $14 \%$ & 433 & $14 \%$ & 4,721 & $15 \%$ \\
\hline Germany & 378 & $13 \%$ & 381 & $13 \%$ & 412 & $13 \%$ & 462 & $14 \%$ & 506 & $15 \%$ & 508 & $15 \%$ & 504 & $15 \%$ & 480 & $15 \%$ & 460 & $14 \%$ & 430 & $14 \%$ & 4,521 & $14 \%$ \\
\hline Greece & 60 & $2 \%$ & 84 & $3 \%$ & 112 & $4 \%$ & 139 & $4 \%$ & 151 & $4 \%$ & 158 & $5 \%$ & 158 & $5 \%$ & 158 & $5 \%$ & 154 & $5 \%$ & 149 & $5 \%$ & 1,323 & $4 \%$ \\
\hline Ireland & 33 & $1 \%$ & 32 & $1 \%$ & 34 & $1 \%$ & 33 & $1 \%$ & 36 & $1 \%$ & 32 & $1 \%$ & 31 & $1 \%$ & 30 & $1 \%$ & 30 & $1 \%$ & 31 & $1 \%$ & 322 & $1 \%$ \\
\hline Italy & 130 & $5 \%$ & 151 & $5 \%$ & 177 & $6 \%$ & 174 & $5 \%$ & 184 & $5 \%$ & 185 & $5 \%$ & 179 & $5 \%$ & 177 & $5 \%$ & 176 & $5 \%$ & 167 & $5 \%$ & 1,700 & $5 \%$ \\
\hline Netherlands & 99 & $4 \%$ & 95 & $3 \%$ & 95 & $3 \%$ & 89 & $3 \%$ & 90 & $3 \%$ & 87 & $3 \%$ & 82 & $2 \%$ & 77 & $2 \%$ & 73 & $2 \%$ & 70 & $2 \%$ & 857 & $3 \%$ \\
\hline Norway & 114 & $4 \%$ & 111 & $4 \%$ & 119 & $4 \%$ & 120 & $4 \%$ & 125 & $4 \%$ & 122 & $4 \%$ & 122 & $4 \%$ & 120 & $4 \%$ & 115 & $4 \%$ & 109 & $4 \%$ & 1,177 & $4 \%$ \\
\hline Portugal & 40 & $1 \%$ & 40 & $1 \%$ & 42 & $1 \%$ & 42 & $1 \%$ & 41 & $1 \%$ & 40 & $1 \%$ & 42 & $1 \%$ & 43 & $1 \%$ & 41 & $1 \%$ & 41 & $1 \%$ & 412 & $1 \%$ \\
\hline Spain & 6 & $0 \%$ & 7 & $0 \%$ & 83 & $3 \%$ & 87 & $3 \%$ & 92 & $3 \%$ & 95 & $3 \%$ & 95 & $3 \%$ & 96 & $3 \%$ & 94 & $3 \%$ & 92 & $3 \%$ & 747 & $2 \%$ \\
\hline Sweden & 247 & $9 \%$ & 247 & $9 \%$ & 260 & $8 \%$ & 270 & $8 \%$ & 292 & $8 \%$ & 308 & $9 \%$ & 307 & $9 \%$ & 308 & $9 \%$ & 303 & $9 \%$ & 292 & $10 \%$ & 2,834 & $9 \%$ \\
\hline $\begin{array}{c}\text { United } \\
\text { Kingdom } \\
\end{array}$ & 933 & $33 \%$ & 962 & $33 \%$ & 1,016 & $32 \%$ & 1,077 & $32 \%$ & 1,106 & $32 \%$ & 1,084 & $31 \%$ & 1,042 & $31 \%$ & 1,003 & $30 \%$ & 983 & $30 \%$ & 890 & $29 \%$ & 10,096 & $31 \%$ \\
\hline Total & 2,813 & $100 \%$ & 2,891 & $100 \%$ & 3,156 & $100 \%$ & 3,331 & $100 \%$ & 3,487 & $100 \%$ & 3,467 & $100 \%$ & 3,390 & $100 \%$ & 3,309 & $100 \%$ & 3,236 & $100 \%$ & 3,046 & $100 \%$ & 32,126 & $100 \%$ \\
\hline
\end{tabular}


Panel B: Number of firms per industry for each year ${ }^{\text {a }}$

\begin{tabular}{|c|c|c|c|c|c|c|c|c|c|c|c|c|c|c|c|c|c|c|c|c|c|c|}
\hline Industry & \multicolumn{2}{|c|}{2005} & \multicolumn{2}{|c|}{2006} & \multicolumn{2}{|c|}{2007} & \multicolumn{2}{|c|}{2008} & \multicolumn{2}{|c|}{2009} & \multicolumn{2}{|c|}{2010} & \multicolumn{2}{|c|}{2011} & \multicolumn{2}{|c|}{2012} & \multicolumn{2}{|c|}{2013} & \multicolumn{2}{|c|}{2014} & \multicolumn{2}{|c|}{ Total } \\
\hline $\begin{array}{l}\text { Agriculture, } \\
\text { Forestry, \& Fishing }\end{array}$ & 17 & $1 \%$ & 17 & $1 \%$ & 18 & $1 \%$ & 21 & $1 \%$ & 22 & $1 \%$ & 23 & $1 \%$ & 26 & $1 \%$ & 29 & $1 \%$ & 27 & $1 \%$ & 23 & $1 \%$ & 223 & $1 \%$ \\
\hline Mining & 103 & $4 \%$ & 128 & $4 \%$ & 154 & $5 \%$ & 186 & $6 \%$ & 222 & $6 \%$ & 246 & $7 \%$ & 263 & $8 \%$ & 266 & $8 \%$ & 255 & $8 \%$ & 237 & $8 \%$ & 2,060 & $6 \%$ \\
\hline Construction & 95 & $3 \%$ & 100 & $3 \%$ & 108 & $3 \%$ & 111 & $3 \%$ & 112 & $3 \%$ & 112 & $3 \%$ & 113 & $3 \%$ & 111 & $3 \%$ & 112 & $3 \%$ & 110 & $4 \%$ & 1,084 & $3 \%$ \\
\hline Manufacturing & 1,274 & $45 \%$ & 1,298 & $45 \%$ & 1,421 & $45 \%$ & 1,493 & $45 \%$ & 1,557 & $45 \%$ & 1,541 & $44 \%$ & 1,503 & $44 \%$ & 1,468 & $44 \%$ & 1,453 & $45 \%$ & 1,382 & $45 \%$ & 14,390 & $45 \%$ \\
\hline Transportation & 261 & $9 \%$ & 277 & $10 \%$ & 314 & $10 \%$ & 330 & $10 \%$ & 348 & $10 \%$ & 350 & $10 \%$ & 340 & $10 \%$ & 343 & $10 \%$ & 328 & $10 \%$ & 320 & $11 \%$ & 3,211 & $10 \%$ \\
\hline Wholesale Trade & 123 & $4 \%$ & 128 & $4 \%$ & 136 & $4 \%$ & 138 & $4 \%$ & 132 & $4 \%$ & 129 & $4 \%$ & 128 & $4 \%$ & 125 & $4 \%$ & 119 & $4 \%$ & 113 & $4 \%$ & 1,271 & $4 \%$ \\
\hline Retail Trade & 185 & $7 \%$ & 178 & $6 \%$ & 185 & $6 \%$ & 186 & $6 \%$ & 184 & $5 \%$ & 184 & $5 \%$ & 168 & $5 \%$ & 156 & $5 \%$ & 152 & $5 \%$ & 143 & $5 \%$ & 1,721 & $5 \%$ \\
\hline Services & 755 & $27 \%$ & 765 & $26 \%$ & 820 & $26 \%$ & 866 & $26 \%$ & 910 & $26 \%$ & 882 & $25 \%$ & 849 & $25 \%$ & 811 & $25 \%$ & 790 & $24 \%$ & 718 & $24 \%$ & 8,166 & $25 \%$ \\
\hline Total & 2,813 & $100 \%$ & 2,891 & $100 \%$ & 3,156 & $100 \%$ & 3,331 & $100 \%$ & 3,487 & $100 \%$ & 3,467 & $100 \%$ & 3,390 & $100 \%$ & 3,309 & $100 \%$ & 3,236 & $100 \%$ & 3,046 & $100 \%$ & 32,126 & $100 \%$ \\
\hline
\end{tabular}


Panel C: Descriptive Statistics on CoD, AQ and Firm Characteristics, 2005-2014

\begin{tabular}{|l|cccc|}
\hline Variable & Mean & 0.250 & Median & 0.750 \\
\hline The cost of debt $(C o D)$ & 0.0936 & 0.0465 & 0.0725 & 0.167 \\
Accruals quality $(A Q)$ & 0.107 & 0.0364 & 0.0652 & 0.123 \\
Leverage & 0.219 & 0.0330 & 0.179 & 0.331 \\
Size (log of total assets) & 5.036 & 3.424 & 4.886 & 6.569 \\
ROA & -0.0447 & -0.0438 & 0.0234 & 0.0623 \\
IntCov & 10.15 & 0.0443 & 4.485 & 20.02 \\
Total Assets (\$ mils) & 2,900 & 30.42 & 132 & 710.1 \\
Sales $(\$$ mils $)$ & 2,200 & 19.91 & 114.5 & 643.7 \\
$\sigma(N I B E)$ & 0.126 & 0.0282 & 0.0558 & 0.126 \\
$\sigma(C F O)$ & 0.111 & 0.0393 & 0.0638 & 0.113 \\
$\sigma($ Sales $)$ & 0.271 & 0.106 & 0.183 & 0.316 \\
Operating Cycle & 5.121 & 4.541 & 5.044 & 5.593 \\
Negative Earnings & 2.451 & 0 & 2 & 4 \\
\hline
\end{tabular}

Panel D: Pearson correlations between CoD, $A Q$ and control variables

\begin{tabular}{|c|c|c|c|c|c|c|c|}
\hline & $C o D$ & $A Q$ & Leverage & Size & ROA & IntCov & $\sigma(N I B E)$ \\
\hline$C o D$ & 1 & & & & & & \\
\hline \multirow[t]{2}{*}{$A Q$} & 0.1525 & 1 & & & & & \\
\hline & $<0.0001$ & & & & & & \\
\hline \multirow[t]{2}{*}{ Leverage } & 0.3172 & -0.056 & 1 & & & & \\
\hline & $<0.0001$ & $<0.0001$ & & & & & \\
\hline \multirow[t]{2}{*}{ Size } & -0.2652 & -0.2981 & 0.2060 & 1 & & & \\
\hline & $<0.0001$ & $<0.0001$ & $<0.0001$ & & & & \\
\hline \multirow[t]{2}{*}{ ROA } & -0.1416 & -0.2704 & -0.0978 & 0.3742 & 1 & & \\
\hline & $<0.0001$ & $<0.0001$ & $<0.0001$ & $<0.0001$ & & & \\
\hline \multirow[t]{2}{*}{ IntCov } & -0.1669 & -0.0236 & -0.3693 & -0.0581 & 0.2723 & 1 & \\
\hline & $<0.0001$ & 0.0053 & $<0.0001$ & $<0.0001$ & $<0.0001$ & & \\
\hline \multirow[t]{2}{*}{$\sigma(N I B E)$} & 0.2229 & 0.2612 & -0.0514 & -0.4755 & -0.4903 & -0.0607 & 1 \\
\hline & $<0.0001$ & $<0.0001$ & $<0.0001$ & $<0.0001$ & $<0.0001$ & $<0.0001$ & \\
\hline
\end{tabular}


Panel E: Institutional characteristics of the European countries

\begin{tabular}{|lcccccc|}
\hline \multicolumn{1}{c}{ Country } & $\begin{array}{c}\text { Legal } \\
\text { Origin }\end{array}$ & $\begin{array}{c}\text { Legal } \\
\text { Tradition }\end{array}$ & ShareProt & LawEnforc & ImpoEquity & $\begin{array}{c}\text { Ownership } \\
\text { Concentration }\end{array}$ \\
\hline Austria & German & CD & 5.5 & 2 & 7 & 0.51 \\
Belgium & French & CD & 7 & 1 & 11.3 & 0.62 \\
Denmark & Scandinavian & CD & 6.5 & 2 & 20 & 0.40 \\
Finland & Scandinavian & CD & 6 & 2 & 13.7 & 0.34 \\
France & French & CD & 5.5 & 1 & 9.3 & 0.24 \\
Germany & German & CD & 5 & 2 & 5 & 0.50 \\
Greece & French & CD & 5.5 & 1 & 11.5 & 0.68 \\
Ireland & English & CM & 8.5 & 2 & 17.3 & 0.36 \\
Italy & French & CD & 6 & 0 & 6.5 & 0.60 \\
Netherlands & French & CD & 4.5 & 2 & 19.3 & 0.31 \\
Norway & Scandinavian & CD & 7 & 2 & 20.3 & 0.31 \\
Portugal & French & CD & 6 & 1 & 11.8 & 0.59 \\
Spain & French & CD & 5.5 & 1 & 7.2 & 0.50 \\
Sweden & Scandinavian & CD & 6.5 & 2 & 16.7 & 0.28 \\
United Kingdom & English & CM & 8.5 & 2 & 25 & 0.15 \\
\hline
\end{tabular}

A,b The sample consists of 32,126 firm-year observations over the period 2005 to 2014 ( 8 industries). Size = the natural logarithm of total assets in year $t$; Leverage $=$ the ratio of total debt to total assets in year $t ; R O A=$ return on assets of a firm in year $t, \operatorname{IntCov}=$ the ratio of operating income to interest expense of a firm in year $t ; \sigma=$ the standard deviation calculated using the previous ten years of data; $\mathrm{CFO}=$ cash flow from operations of a firm; Sales = net sales revenue of a firm; OperCycle $=$ the natural logarithm of operating cycle of a firm in year $t$, NegEarn $=$ the number of negative earnings that a firm reported annually out of the previous ten years. ShareProt is the Strength of Investor Protection index, which is based on the average of three indices measuring the extent of disclosure, the extent of director liability and the ease of investor suits in each country. LawEnforc is the Rule of Law index, which is used as a measure of legal rules, and it is measured using the average of four variables: the court system, the police, the contract enforcement quality and property rights. ImpoEquity is the Importance of Equity Market which is measured by the average of three variables used in La Porta et al. (1997): (1) the total stock market capitalization owned by minorities divided by the GNP; (2) the number of listed domestic firms divided by the total population of firms in the country; and (3) the number of IPOs divided by total firms in the country. Each variable is ranked such that higher scores show a significant importance of the stock market. Legal Origin is based on La Porta et al. (1998). All countries are classified into 4 main groups: German, French, English and Scandinavian. Legal Tradition is based on La Porta et al., (1998), all countries are classified into two main groups: Code-law (CD) and Common-law (CM). 
Table 2

The average values of $\mathrm{CoD}$ by $\mathrm{AQ}$ quintiles

\begin{tabular}{|c|c|c|c|c|}
\hline & $\begin{array}{c}\text { High } \\
\mathrm{Q} 1\end{array}$ & $\begin{array}{c}\text { Low } \\
\mathrm{Q} 10\end{array}$ & $\begin{array}{c}\text { Diff } \\
\mathrm{Q} 10-\mathrm{Q} 1\end{array}$ & t-stat \\
\hline$\frac{2005-2014}{\boldsymbol{C o D}}$ & 0.079 & 0.114 & 0.034 & $\mathbf{2 6 . 2 9} * * *$ \\
\hline$\frac{\text { In the pre-crisis period }}{\boldsymbol{C o D}}$ & 0.081 & 0.104 & 0.024 & $\mathbf{9 . 1 9} * * *$ \\
\hline$\frac{\text { In the crisis period }}{\boldsymbol{C o D}}$ & 0.069 & 0.108 & 0.039 & $\mathbf{1 4 . 2 7 * * *}$ \\
\hline
\end{tabular}

This table shows the mean of $C o D$ per $A Q$ quintile. The column named (Q10-Q1) shows the differences in the average of $C o D$ between the lower quantile (Q10) and higher quintile (Q1).

$\mathrm{t}$-statistics test shows whether the difference between the two quantiles is zero.

$* * *$ p-value $<0.01, * *$ p-value $<0.05, *$ p-value $<0.1$. 
Table 3

Regression of $C o D$ on $A Q$ proxy (Decile rank)

\begin{tabular}{|c|c|}
\hline & $C o D$ \\
\hline Leverage & $\begin{array}{c}-0.053^{\text {*** }} \\
(-29.7)\end{array}$ \\
\hline Size & $\begin{array}{c}-0.0028^{* * *} \\
(-18.9)\end{array}$ \\
\hline ROA & $\begin{array}{c}-0.025^{* * *} \\
(-16.8)\end{array}$ \\
\hline IntCov & $\begin{array}{c}0.00036^{* * *} \\
(16.4)\end{array}$ \\
\hline$\sigma(N I B E)$ & $\begin{array}{c}0.029^{* * *} \\
(11.5)\end{array}$ \\
\hline AQ Decile & $\begin{array}{c}0.0014^{* * *} \\
(8.87)\end{array}$ \\
\hline Crisis & $\begin{array}{c}0.0026^{* * *} \\
(3.89)\end{array}$ \\
\hline Crisis \# $A Q$ & $\begin{array}{c}0.0015^{* * *} \\
(9.32)\end{array}$ \\
\hline PostCrisis \# $A Q$ & $\begin{array}{c}0.00044^{* *} \\
(1.99)\end{array}$ \\
\hline ShareProt & $\begin{array}{c}-0.0020^{* *} \\
(-1.97)\end{array}$ \\
\hline LawEnforc & $\begin{array}{c}-0.015^{* * *} \\
(-11.8)\end{array}$ \\
\hline LegalTradition & $\begin{array}{c}0.011^{* * *} \\
(6.81)\end{array}$ \\
\hline LegalOrigin & $\begin{array}{c}-0.0025^{* *} \\
(-2.45)\end{array}$ \\
\hline ImpoEquity & $\begin{array}{c}-0.00060^{* * *} \\
(-6.51)\end{array}$ \\
\hline Constant & $\begin{array}{c}0.072^{* * *} \\
(11.5)\end{array}$ \\
\hline $\begin{array}{l}N \\
\operatorname{adj} . R^{2}\end{array}$ & $\begin{array}{c}32,126 \\
0.197\end{array}$ \\
\hline
\end{tabular}

See Table 1 for variables measurement.

The sample comprises of 32,126 firm-year observations over the period 2005 to 2014.

$* * *$ p-value $<0.01, * *$ p-value $<0.05, *$ p-value $<0.1$. 


\section{Table 4}

Regression of $C o D$ on Innate $A Q$ and $D i s c A Q$ (decile rank)

\begin{tabular}{|c|c|}
\hline & $C o D$ \\
\hline Leverage & $\begin{array}{c}-0.054^{* * *} \\
(-34.6)\end{array}$ \\
\hline Size & $\begin{array}{c}0.00091^{* * *} \\
\quad(4.09)\end{array}$ \\
\hline ROA & $\begin{array}{c}-0.025^{* * *} \\
(-17.3)\end{array}$ \\
\hline $\operatorname{IntCov}$ & $\begin{array}{c}0.00049^{* * *} \\
(24.3)\end{array}$ \\
\hline$\sigma(N I B E)$ & $\begin{array}{c}0.011^{* * *} \\
(4.25)\end{array}$ \\
\hline Innate $A Q$ & $\begin{array}{c}0.0046^{* * *} \\
(19.4)\end{array}$ \\
\hline Disc $A Q$ & $\begin{array}{c}0.00078^{* * *} \\
(4.29)\end{array}$ \\
\hline Crisis & $\begin{array}{c}0.00063 \\
(0.61)\end{array}$ \\
\hline Crisis\# InnatAQ & $\begin{array}{c}0.00038^{*} \\
(1.79)\end{array}$ \\
\hline PostCrisis\# Innat $A Q$ & $\begin{array}{c}0.00075^{* * *} \\
\quad(3.22)\end{array}$ \\
\hline Crisis\# DiscAQ & $\begin{array}{c}-0.0010^{* * *} \\
(-4.92)\end{array}$ \\
\hline PostCrisis\# DiscAQ & $\begin{array}{c}0.00027 \\
(1.18)\end{array}$ \\
\hline ShareProt & $\begin{array}{c}-0.00042 \\
(-0.41)\end{array}$ \\
\hline LawEnforc & $\begin{array}{c}0.015^{* * * *} \\
(11.7)\end{array}$ \\
\hline LegalTradition & $\begin{array}{c}0.017^{* * *} \\
(10.9)\end{array}$ \\
\hline LegalOrigin & $\begin{array}{c}-0.0021^{* *} \\
(-2.01)\end{array}$ \\
\hline ImpoEquity & $\begin{array}{c}0.000024 \\
(0.23)\end{array}$ \\
\hline Constant & $\begin{array}{c}0.021^{* * * *} \\
(3.16)\end{array}$ \\
\hline $\begin{array}{l}N \\
\text { adj. } R^{2}\end{array}$ & $\begin{array}{c}31,865 \\
0.217 \\
\end{array}$ \\
\hline
\end{tabular}

See Table 1 for variables measurement.

The sample comprises of 31,865 firm-year observations covers the period from 2005 to 2014 .

$* * *$ p-value $<0.01, * *$ p-value $<0.05, *$ p-value $<0.1$. 


\section{Table 5}

\section{Regression of $C o D$ on $A Q$ (raw values)}

\begin{tabular}{|c|c|}
\hline & $C o D$ \\
\hline Leverage & $\begin{array}{c}-0.056^{* * *} \\
(-35.7)\end{array}$ \\
\hline Size & $\begin{array}{c}-0.0031^{* * *} \\
(-20.7)\end{array}$ \\
\hline ROA & $\begin{array}{c}-0.024^{* * *} \\
(-16.5)\end{array}$ \\
\hline IntCov & $\begin{array}{c}0.00037^{* * *} \\
\quad(18.9)\end{array}$ \\
\hline$\sigma(N I B E)$ & $\begin{array}{c}0.031^{* * *} \\
(12.4)\end{array}$ \\
\hline$A Q$ & $\begin{array}{c}0.022^{* * * *} \\
(6.11)\end{array}$ \\
\hline Crisis & $\begin{array}{c}0.0038^{* * *} \\
(8.82)\end{array}$ \\
\hline Crisis \# $A Q$ & $\begin{array}{c}-0.035^{* * *} \\
(-6.88)\end{array}$ \\
\hline PostCrisis \# $A Q$ & $\begin{array}{c}0.012^{* *} \\
(2.28)\end{array}$ \\
\hline ShareProt & $\begin{array}{c}-0.00063 \\
(-0.60)\end{array}$ \\
\hline LawEnforc & $\begin{array}{c}0.015^{\text {*** }} \\
(11.0)\end{array}$ \\
\hline LegalTradition & $\begin{array}{c}0.017^{* * *} \\
(10.6)\end{array}$ \\
\hline LegalOrigin & $\begin{array}{c}-0.0016 \\
(-1.50)\end{array}$ \\
\hline ImpoEquity & $\begin{array}{c}0.000068 \\
(0.65)\end{array}$ \\
\hline Constant & $\begin{array}{c}0.067^{* * *} \\
(10.5)\end{array}$ \\
\hline $\begin{array}{l}N \\
\text { adj. } R^{2}\end{array}$ & $\begin{array}{c}32,126 \\
0.198 \\
\end{array}$ \\
\hline
\end{tabular}

See Table 1 for variables measurement.

The sample comprises of 32,126 firm-year observations covers the period from 2005 to 2014 .

$* * *$ p-value $<0.01, * *$ p-value $<0.05, *$ p-value $<0.1$. 


\section{Table 6}

Fixed and random panel regressions of $C o D$ on $A Q$ (decile rank)

\begin{tabular}{|l|c|c|}
\hline & Fixed & Random \\
& $C o D$ & $C o D$ \\
\hline Leverage & $-0.030^{* * *}$ & $-0.046^{* * *}$ \\
& $(-12.2)$ & $(-23.8)$ \\
Size & $-0.0032^{* * *}$ & $-0.0041^{* * *}$ \\
& $(-4.92)$ & $(-17.1)$ \\
ROA & $-0.010^{* * *}$ & $-0.017^{* * *}$ \\
IntCov & $(-5.68)$ & $(-11.1)^{* * *}$ \\
& $0.00028^{* * *}$ & $0.00033^{* * *}$ \\
$\sigma(N I B E)$ & $(10.6)$ & $(15.1)^{* * *}$ \\
& 0.0011 & $0.029^{* * *}$ \\
AQ Decile & $(0.20)$ & $(8.94)$ \\
& $0.00034^{* *}$ & $0.00081^{* * *}$ \\
Constant & $(2.20)$ & $(6.39)$ \\
& $0.11^{* * *}$ & $0.11^{* * *}$ \\
$N$ & $(28.5)$ & $(65.5)$ \\
$R^{2}$ & 32,126 & 32,126 \\
Hausman & 0.1564 & 0.1669 \\
\hline
\end{tabular}

See Table 1 for variables measurement.

The sample comprises of 32,126 firm-year observations covers the period from 2005 to 2014

$* * *$ p-value $<0.01, * *$ p-value $<0.05, *$ p-value $<0.1$ 